\title{
Expression of adrenomedullin and adrenomedullin mRNA in ectopic ACTH-secreting tumors
}

\author{
Osamu Murakami ${ }^{1}$, Kazuhiro Takahashi ${ }^{2}$, Fumitoshi Satoh $^{1}$, Kazuhito Totsune ${ }^{1}$, Masahiko Sone ${ }^{2,4}$, \\ Zenei Arihara ${ }^{1}$, Noriaki Andoh ${ }^{3}$ and Toraichi Mouri ${ }^{5}$ \\ ${ }^{1}$ Second Department of Internal Medicine, ${ }^{2}$ Department of Molecular Biology and ${ }^{3}$ Department of Pathology. Tohoku University School of Medicine, \\ Sendai, Miyagi 980-77, Japan, ${ }^{4}$ Department of Internal Medicine, the National Iwate Hospital, Ichinoseki, Iwate 021, Japan, and ${ }^{5}$ Division of \\ Neuroendocrinology, Mouri Clinic, Natori, Miyagi 981-12, Japan
}

(Correspondence should be addressed to K Takahashi, Department of Molecular Biology, Tohoku University School of Medicine, 2-1 Seiryo-machi, Aoba-ku, Sendai, Miyagi 980-8575, Japan)

\begin{abstract}
Objective: To study the expression of adrenomedullin, a potent vasodilator peptide originally isolated from a pheochromocytoma, in ectopic ACTH-secreting tumors.

Methods: Tumor tissue concentrations of adrenomedullin, calcitonin gene-related peptide, neuropeptide Y, endothelin-1, corticotropin-releasing hormone and ACTH were measured in three ectopic ACTH-secreting tumors by RIA. The expression of adrenomedullin mRNA was examined by northern blot analysis of tissue from one of the tumors.

Results: Immunoreactive adrenomedullin was detected in tumor tissues of three ectopic ACTHsecreting tumors $(0.60-18.5 \mathrm{pmol} / \mathrm{g}$ wet weight). Calcitonin gene-related peptide, neuropeptide Y, endothelin-1 and corticotropin-releasing hormone were also detected in the tumor tissues. The tumor tissue concentrations of immunoreactive adrenomedullin were comparable to those of these four peptides, but much lower than those of ACTH. Northern blot analysis showed the expression of adrenomedullin mRNA in one tumor from which sufficient tissue was available for such study. The plasma concentration of immunoreactive adrenomedullin was increased in one patient $(41.3 \mathrm{pmol} / \mathrm{l}$, control $13.5 \pm 3.6 \mathrm{pmol} / \mathrm{l}$, mean \pm s.D., $n=12$ ).

Conclusions: These results suggest that adrenomedullin is produced by ectopic ACTH-secreting tumors, together with other neuropeptides, and raise the possibility that adrenomedullin is related to the pathophysiology of these tumors.
\end{abstract}

European Journal of Endocrinology 138 436-439

\section{Introduction}

Adrenomedullin (ADM) is a potent vasodilator peptide that was originally isolated from human pheochromocytoma (1). The C-terminal portion (16-52) of ADM has about $27 \%$ homology with calcitonin gene-related peptide (CGRP). ADM has been shown to regulate the production and secretion of some hormones, such as ACTH $(2)$ and aldosterone $(3,4)$, and to modulate the proliferation and differentiation of cells (5).

ADM mRNA and ADM receptor mRNA are expressed in various kinds of tumors, including pulmonary tumors (6). ADM is produced and secreted by cultured choroid plexus carcinoma cells (7) and by cultured glioblastoma cells (8). It is known that ectopic ACTHsecreting tumors produce and secrete not only ACTH but also other peptides, such as calcitonin. We reported the presence of immunoreactive (IR)-endothelin, IRneuropeptide Y (NPY), and IR-corticotropin-releasing hormone (CRH) in the tumor tissue of an ectopic ACTHsecreting bronchial carcinoid tumor (9). There is no information on ADM in ectopic ACTH-secreting tumors. We therefore studied the expression of ADM and ADM mRNA in tumor tissue of ectopic ACTH-secreting tumors.

\section{Materials and methods}

\section{Samples}

Tumor tissues were obtained at surgery from three patients with ectopic ACTH-secreting tumors (Table 1a). Tumor tissues were stored at $-80^{\circ} \mathrm{C}$ until required for the extraction of peptides and RNA. All the patients had increased plasma concentrations of ACTH and cortisol (Table 1a). After surgery, plasma concentrations of ACTH and cortisol were decreased and patients 1 and 3 
Table 1 Clinical characteristics and results of analyses of plasma IR-ADM concentrations and tumor tissue concentrations of IR-ADM, $\mathrm{ACTH}$ and four other peptides in three patients with ectopic ACTH- secreting tumors.

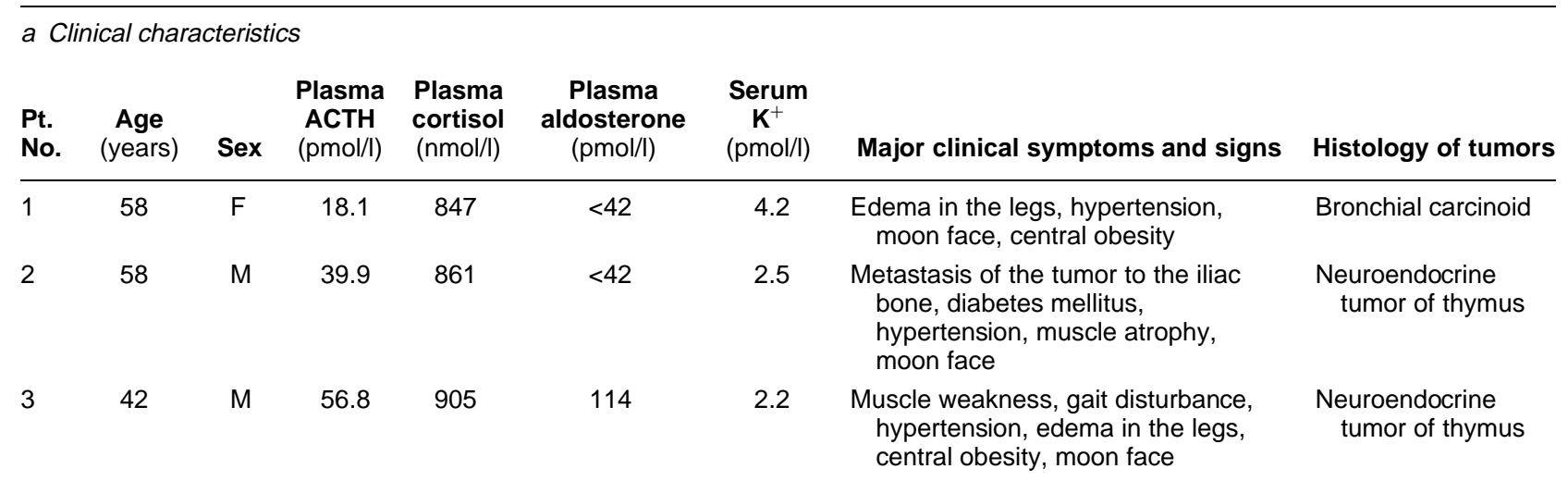

b Results of analyses

Tumor tissue concentrations ( $\mathrm{pmol} / \mathrm{g}$ wet weight)

\begin{tabular}{lccrrrrr}
\cline { 3 - 7 } Pt. & $\begin{array}{c}\text { Plasma } \\
\text { ADM }\end{array}$ & & & & & & \\
No. & (pmol/l) & ADM & CGRP & NPY & ET & CRH & ACTH \\
\hline 1 & n.e. & 0.60 & 45.7 & 8.4 & 3.37 & 1.76 & 3702 \\
2 & 17.5 & 2.32 & 0.8 & 24.6 & 0.19 & 0.62 & 22 \\
3 & 41.3 & 18.5 & 0.1 & 37.8 & 0.11 & 0.11 & 309
\end{tabular}

Pt, patient; n.e., not examined; ADM, adrenomedulin; CGRP, calcitonin gene-related peptide; NPY, neuropeptide Y; ET, endothelin; CRH, corticotropin-releasing hormone.

received dexamethasone $(0.5 \mathrm{mg} /$ day $)$. In patient 2 , plasma concentrations of ACTH and cortisol were decreased after surgery, but only to approximately 50\% of the preoperative values, possibly because of a metastasis of the tumor in the iliac bone. Plasma samples for the measurement of IR-ADM were available from patients 2 and 3. Control plasma samples were obtained from 12 healthy subjects (seven men and five women, 21-40 years old). The study was approved by the Ethics Committee of Tohoku University School of Medicine.

\section{RIA and chromatography}

Tumor tissues were extracted as previously reported (10). Plasma samples were extracted by Sep-Pak C18 cartridges (Waters, Milford, MA, USA). Plasma (2 ml) was acidified with $2 \mathrm{ml} 0.75 \mathrm{~mol} / \mathrm{l}$ acetic acid containing $0.5 \%(\mathrm{w} / \mathrm{v})$ casein (Wako Pure Chemical Industries, Ltd, Osaka, Japan) and loaded onto the cartridge, which was pretreated with $10 \mathrm{ml}$ acetonitrile, $10 \mathrm{ml}$ methanol and then $10 \mathrm{ml} 0.75 \mathrm{~mol} / \mathrm{l}$ acetic acid. The peptide was eluted with $2 \mathrm{ml} 60 \%(\mathrm{v} / \mathrm{v})$ acetonitrile-water containing $0.1 \%(\mathrm{v} / \mathrm{v})$ trifluoroacetic acid from the cartridge. The eluate was air-dried, reconstituted with assay buffer and assayed. The recovery of this extraction method ranged from $55 \%$ to $61 \%$.

The ADM RIA was performed using the antiserum against human $\operatorname{ADM}(1-52)$ (No. 102), as previously reported $(7,11)$. The assay showed less than $0.001 \%$ cross reactivity with other peptides such as $\alpha$ CGRP. IRCGRP, IR-NPY, IR-endothelin, IR-CRH and IR-ACTH in the tumor tissues were measured by RIA as described previously $(9,12-14)$. The CGRP RIA showed less than $0.01 \%$ crossreaction with human $\operatorname{ADM}(1-52)$. The endothelin RIA was performed using an antiserum against endothelin-1 (BP6), which was kindly supplied by Prof. S R Bloom and Dr M A Ghatei (Royal Postgraduate Medical School, London, UK). The endothelin assay showed $60 \%$ crossreactivity with endothelin-2 and 70\% with endothelin-3 (14).

IR-ADM in the tissue extracts was characterized by reverse-phase HPLC using a $\mu$ Bondapak C18 column (3.9 $\mathrm{mm} \times 300 \mathrm{~mm}$, Waters) as reported previously (7).

\section{RNA extraction and northern blot analysis}

Tumor tissue for RNA extraction was available only from patient 3. Total RNA was extracted by the guanidine thiocyanate-cesium chloride method and subjected to northern blot analysis as reported previously (7). The tumor tissue of a pheochromocytoma obtained from a 63-year-old female patient was included as a positive control. The HindIII/EcoRI fragment of pBShAM2 (7) was labeled with $\left[\alpha^{-32} \mathrm{P}\right] \mathrm{dCTP}$ by the random priming method and was used as a hybridization probe. Expression of $\beta$-actin mRNA was examined as an internal control. 


\section{Results}

IR-ADM was detected in all three tumor tissues of ectopic ACTH-secreting tumors (0.60-18.5 pmol/g wet weight) (Table $1 b$ ). Reverse phase HPLC of the tumor tissue extracts of these three patients showed a single immunoreactive peak eluting in the position of human $\operatorname{ADM}(1-52)$ (data not shown). CGRP, NPY, endothelin and $\mathrm{CRH}$ were also detected in the tumor tissues of these ectopic ACTH-secreting tumors (Table $1 b$ ). The concentrations of IR-ADM in the tumor tissues were comparable to those of these four peptides, but much lower than those of ACTH.

The plasma concentration of IR-ADM was increased in patient 3 (41.3 pmol/l; control, $13.5 \pm 3.6 \mathrm{pmol} / \mathrm{l}$, mean \pm S.D., $n=12)$, but not in patient $2(17.5 \mathrm{pmol} / \mathrm{l})$ (Table $1 b$ ).

Northern blot analysis of the total RNA prepared from the tumor tissue of patient 3 showed the expression of ADM mRNA (Fig. 1) at a level comparable to that in a pheochromocytoma.

\section{Discussion}

The present study has shown the expression of ADM and ADM mRNA in the tumor tissues of ectopic ACTHsecreting tumors. The tumor tissue concentrations of IR-ADM were comparable to those in pheochromocytomas in our previous study (11). The tumor tissue

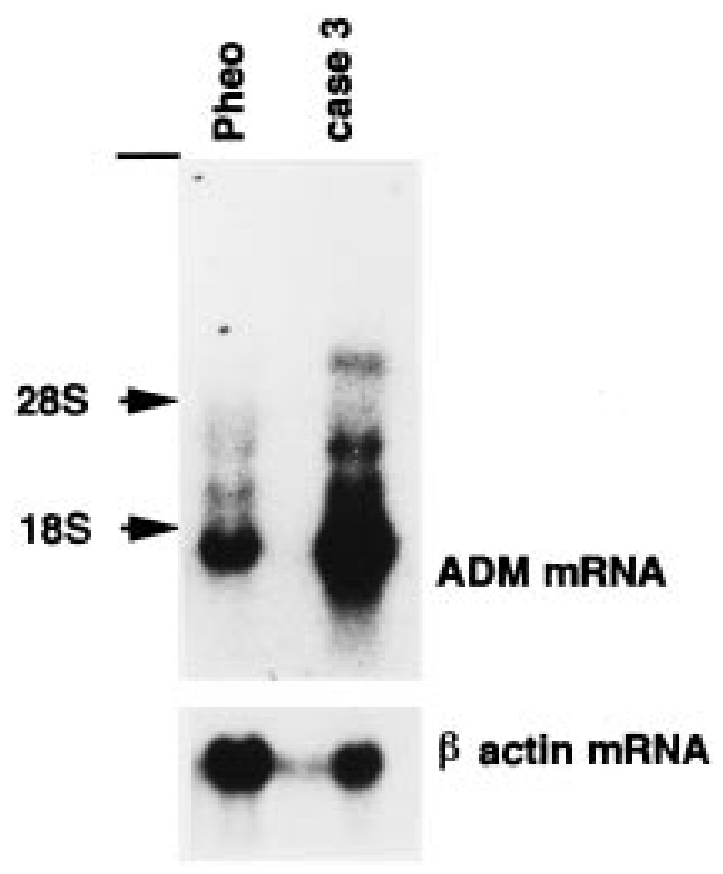

Figure 1 Northern blot analysis of adrenomedullin mRNA in the tumor tissue of an ectopic ACTH-secreting tumor (patient 3). The tumor tissue of a pheochromocytoma (Pheo) was included as a positive control. The lower panel shows the expression of $\beta$-actin mRNA as an internal control. concentration of IR-ADM in patient $3(18.5 \mathrm{pmol} / \mathrm{g}$ wet weight) was greater than the concentrations in normal adrenal glands (12.6 $\pm 1.0 \mathrm{pmol} / \mathrm{g}$ wet weight) (11). The tumor tissue concentrations of IR-ADM in patients 1 and 2 were comparable to those in human brain (0.26-1.4 $\mathrm{pmol} / \mathrm{g}$ wet weight) (11). In addition, an increased plasma concentration of IR-ADM was found in one patient, suggesting that ADM secreted from the tumor may contribute to plasma IR-ADM concentrations in some patients. Our findings concerning the presence of IR-NPY, IR-endothelin and IR-CRH in the tumor tissues are compatible with those of our previous study (9). The present study has also shown the presence of IR-CGRP in these tumor tissues.

It has been reported that ADM has a direct inhibitory effect on the secretion of aldosterone $(3,4)$ and an indirect stimulatory effect on it, possibly through catecholamine release (4). Rat $\operatorname{ADM}(11-50)$ inhibited ACTH release from dispersed rat anterior pituitary cells (2). ADM secreted from ectopic ACTH-secreting tumors may modulate signs and symptoms in patients with these tumors. Low plasma concentrations of aldosterone were found in all three of our patients. An increased plasma concentration of IR-ADM was observed only in one of them (patient 3), however, and further studies are required to clarify the effects of $\mathrm{ADM}$ on signs and symptoms in these patients. Another possible pathophysiological role of ADM in ectopic ACTH-secreting tumors may be through local actions on the differentiation and proliferation of tumor cells. It has been reported that ADM stimulated DNA synthesis and cell proliferation via increases in cAMP in Swiss 3T3 cells (4). In this regard, endothelin-1 is known to have a mitogenic action (15). ADM produced by the tumor may act locally on the growth and differentiation of the tumor, together with endothelin-1. The findings of the present study suggest possible pathophysiological roles of ADM, in addition to CGRP, NPY, endothelin-1 and $\mathrm{CRH}$, in ectopic ACTH-secreting tumors.

\section{Acknowledgements}

We are grateful to Ms K Kikuchi for excellent technical assistance. This study was supported in part by a research grant for medical science from the Nippon University Alumni Association (to M S), a Grant-in-aid for Scientific Research (C) (No. 09670117) from the Ministry of Education, Science, Sports and Culture of Japan (to K T), a Grant-in-aid for Brain Science Research from the Ministry of Health and Welfare of Japan (to K T), and by the Gonryou Medical Foundation (to $\mathrm{K} \mathrm{T}$ ).

\section{References}

1 Kitamura K, Kangawa K, Kawamoto M, Ichiki Y, Nakamura S, Matsuo H \& Eto T. Adrenomedullin: a novel hypotensive peptide isolated from human pheochromocytoma. Biochemical and Biophysical Research Communications 1993192 553-560. 
2 Samson WK, Murphy T \& Schell DA. A novel vasoactive peptide adrenomedullin, inhibits pituitary adrenocorticotropin release. Endocrinology 1995136 2349-2352.

3 Yamaguchi T, Baba K, Doi Y, Yano K, Kitamura K \& Eto T. Inhibition of aldosterone production by adrenomedullin, a hypotensive peptide, in the rat. Hypertension $199628308-314$.

4 Andreis PG, Neri G, Prayer-Galetti T, Rossi GP, Gottardo G, Malendowicz LK \& Nussdorfer GG. Effects of adrenomedullin on the human adrenal glands: an in vitro study. Journal of Clinical Endocrinology and Metabolism 199782 1167-1170.

5 Withers DJ, Coppock HA, Seufferlein T, Smith DM, Bloom SR \& Rozengurt E. Adrenomedullin stimulates DNA synthesis and cell proliferation via elevation of cAMP in Swiss 3T3 cells. FEBS Letters 1996378 83-87.

6 Miller MJ, Martinez A, Unsworth EJ, Thiele CJ, Moody TW, Elsassr T \& Cuttitta F. Adrenomedullin expression in human tumor cell lines. Journal of Biological Chemistry $199627123345-$ 23351.

7 Takahashi K, Satoh F, Hara E, Murakami O, Kumabe T, Tominaga T, Kayama T, Yoshimoto $\mathrm{T} \&$ Shibahara S. Production and secretion of adrenomedullin by cultured choroid plexus carcinoma cells. Journal of Neurochemistry 199768 726-731.

8 Takahashi K, Satoh F, Hara E, Sone M, Murakami O, Kayama T, Yoshimoto $\mathrm{T} \&$ S Shibahara $\mathrm{S}$. Production and secretion of adrenomedullin from glial cell tumors and its effects on cAMP production. Peptides 199718 1117-1124.

9 Murakami O, Takahashi K, Sone M, Totsune K, Ohneda M, Itoi K, Yoshinaga K \& Mouri T. An ACTH-secreting bronchial carcinoid: presence of corticotropin-releasing hormone, neuropeptide $\mathrm{Y}$ and endothelin-1 in the tumor tissue. Acta Endocrinologica 1993128 192-196.
10 Takahashi K, Totsune K, Sone M, Ohneda M, Murakami O, Itoi K \& Mouri T. Human brain natriuretic peptide-like immunoreactivity in human brain. Peptides 199213 121-123.

11 Satoh F, Takahashi K, Murakami O, Totsune K, Sone M, Ohneda M, Abe K, Miura Y, Hayashi Y, Sasano H \& Mouri T. Adrenomedullin in human brain, adrenal glands and tumor tissues of pheochromocytoma, ganglioneuroblastoma and neuroblastoma. Journal of Clinical Endocrinology and Metabolism 1995 80 1750-1752.

12 Mouri T, Takahashi K, Sone M, Murakami O, Ohneda M, Itoi K, Imai Y, Yoshinaga K \& Sasano N. Calcitonin gene-related peptidelike immunoreactivities in pheochromocytomas. Peptides 1989 10 201-204.

13 Mouri T, Sone M, Takahashi K, Itoi K, Totsune K, Hayashi Y, Hasegawa S, Ohneda M, Murakami O, Miura Y, Katakura R, Tachibana S \& Maebashi M. Neuropeptide Y as a plasma marker for phaeochromocytoma, ganglioneuroblastoma and neuroblastoma. Clinical Science $199283205-211$.

14 Takahashi K, Ghatei MA, Jones PM, Murphy JK, Lam H-C, O'Halloran DJ \& Bloom SR. Endothelin in human brain and pituitary gland: presence of immunoreactive endothelin, endothelin messenger ribonucleic acid, and endothelin receptors. Journal of Clinical Endocrinology and Metabolism 199172 693699.

15 Komuro I, Kurihara H, Sugiyama T, Takaku F \& Yazaki Y. Endothelin stimulates c-fos and c-myc expression and proliferation of vascular smooth muscle cells. FEBS Letters 1988238 249-252.

Received 1 July 1997

Accepted 22 December 1997 